\title{
THE PECULIARITIES OF THE STATE REGULATION OF THE TERRITORIAL INTERCOURSE IN THE COUNTRIES OF THE COMMONWEALTH OF INDEPENDENT STATES
}

\section{Stratonov V. M., Gavlovskaya A. O., Pavlish P. V.}

\section{INTRODUCTION}

The investigation of the state regulation of the territorial intercourse in the countries of CIS is based on the theoretical notion "the state regulation of the economical intercourse" that is related to the territorial intercourse.

The given notion is identified in different ways by various scholars. Thus, this notion is identified as:

- the state regulation of the economical business, namely, the influence of the state in a person of the state agency on economical objects, processes and personalities that take part in such a business including the prognostication, the planning, the financing, the budgeting, the taxation, the administration, the accounting and the control ${ }^{1}$;

- the state regulation of the economics as the system of activities for the creation of the supporting, the compensational, the regulative activity of the state leaded on the creation of the normal conditions of the effective functioning of the market and the solvation of complex social and economic problems of the development of the national economics and the whole society $^{2}$;

- the state regulation of the economics is the regulation of the economics by means of the direct and the indirect intervention (the direct intervention is the acceptance of the legislative acts aimed on the ordering and the development of the business between all the elements of the market system; the indirect intervention comprises various ways of the economical politics depending on the aim of the intervention $)^{3}$.

Thus, the state regulation of the economics is identified in the scientific paradigm as the influence on the economic intercourse with the help of the direct and the indirect action by means of the system of activities of the state agencies.

${ }^{1}$ Борисов А.Б. Большой экономический словарь / А.Б. Борисов. М.: Книжный мир, 2003. C.283.

2 Стеченко Д.М. Державне регулювання економіки: Навч. посіб. 3-тє вид., випр. Рекомендовано МОН / Д.М. Стеченко. К., 2006. С.189.

3 Прямое и косвенное государственное регулирование экономики. URL: http://econtool.com/gosudarstvennoe-regulirovanie-ekonomiki.html.(дата звернення 12.02.20) 


\section{The State Regulation of the Territorial Intercourse in the Countries of the Commonwealth of Independent States (CIS)}

It should be mentioned that there is the difference between the scientific identification on the notion "the state regulation of the territorial intercourse". L.A. Shwayka states that the state regulation of the territorial intercourse is "the creation of the legislative basis on the protection of rights of the territoryowners and the territory-users in the choice of the effective proportions between the direct and the indirect administration of the territorial recourses"4.

O.S. Damdin points out that the state regulation of the territorial intercourse "leaded on the organization of the rational usage of the territory and it's protection by means of the creation of rules and norms of the possession, the usage and the order of the territorial recourses of the state". N.I. Kalinin states that the state regulation of the territorial intercourse is "the purposeful activity of state agencies of the organization of the rational usage of lands and their defense by means of the usage of the economical and the legal activities",

Summarizing the above mentioned definitions we propose the following identification of the state regulation of the territorial intercourse as the purposeful activity of the state agencies of the legal, of the economical and of the organizational nature that is aimed on the regulation of the business in the sphere of the rational usage of lands, their protection, the defense of rights of the territory-owners and the territory-users.

On the basis of the given definition we point out the following objective reasons of the necessity of the state regulation of the territory intercourse: the peculiar multifunctional role of the territory in the life of a society; the natural restriction and the irreplaceability of the land; the rational usage of the territory; the protection of rights and interests of subjects of law; the elimination of negative results of the market processes in the sphere of the territorial business; the protection of the state and the national interests; the creation of the effective conditions for the functioning of the territorial market; the creation of the state and the social needs and priorities of the development; the providing of the security and the protection of the state; the need of "the balancing" of the direct and the indirect methods of the state regulation of the territorial intercourse and so on.

4 Швайка Л.А. Государственное регулирование экономики: Учебное пособие / Л.А. Швайка. К.: Знание, 2006. С. 156.

${ }^{5}$ Дамдын О.С. Государственное регулирование земельных отношений / О.С. Дамдын // Молодой ученый, 2011. № 5. Т. 1. С. 175-177.

6 Калинин Н.И. Правовое регулирование земельных отношений в России / Н.И. Калинин. М.: Кооперационный проект "Германо-Российский аграрно- политический диалог", 2011. С. 2. 
Among the variations of the state regulation of the territorial business are identified the following types:

1. The regulation of the territorial intercourse by the state as the sovereign that has the territorial priority on all the territories in spite of the forms of the ownership. The Constitutional basis of such a kind of the state regulation of the territorial intercourse is defined by the majority of Constitutions of CIS. For example, according to the Article 55 of the Constitution of Kazakhstan Republic "the land, it's subsoil, water, floral and animal world and other natural resources are the national wealth and should be used rationally and are protected by the state". The Article 13 of the Constitution of Tajikistan Republic is the evidence that "the land, it's subsoil, water, air space, floral and animal world, and other natural resources are the property of the state and the state guarantees the effective usage according to the interests of the nationality" ". In the Point 5 of the Article 12 of the Constitution of Kyrgyzstan Republic is pointed out that "the land, it's subsoil, air space, water, forests, floral and animal world and other natural resources are the property of Kyrgyzstan Republic and are used for the safe of the ecological system as the basis of life and activity of the nationality of Kyrgyzstan Republic and are protected by the state" 8 .

The conclusion: the objective need of the regulation of the territorial business by the state as the sovereign is determined by the fact that the land as the basis of the life of nationalities is the property of the state and is protected by it.

2. The economic regulation of the territorial intercourse is made by the state agencies as the economic subjects that have the power to give land properties to physical and judicial personalities, lead the accounting, the evaluation, the protection of lands etc ${ }^{9}$. For example, the evaluation of land resources in Moldova Republic is made by the Parliament on the basis of the acts of the Law of Moldova Republic "The Normative Price and the Order of the Buying-Selling of Land Properties” № 1308 - XIII dated by 25.07.1997: rates for the calculation of the normative price are identified by the conditional unit - the ball-hectare according to the inventory (quantitative and qualitative) results according the appendix that is the part of the mentioned law and is rated annually by the Parliament as for the presentation of the state

7 Конституція Республіки Таджикистан від 06.11.1994. URL: http:// www.tajikistan.turkestan.ru/constitution/. (дата звернення 02.02.2020)

${ }^{8}$ Конституція Киргизької Республіки від 05.05.1993. URL: http://www.gov.kg/?page_id= 263\&lang=ru. (дата звернення 02.02.2020).

9 Дамдын О.С. Государственное регулирование земельных отношений / О.С. Дамдын // Молодой ученый. 2011., № 5., Т. 1. С. 175. 
while the approval of the state budget according to the level of the inflation" (Point 2, Article 2) ${ }^{10}$.

The example of the pointing out of the protection of lands in the state may be Point 1 in Article 139 of the Territorial Code of Kazakhstan Republic "the protection of lands comprises the system of legal, organizational, economic, technical and other activities leaded on the protection of lands as the part of the ecosystem, the rational usage of territories, the liquidation of the non-legal exclusion of lands from the agricultural and the forest circulation and the revival and the increasing of the futility of soils"11.

As O.S. Damdin states: "the state regulation of territories is subdivided on the general - that is done by the state agencies of the common and the special competencies and that is widespread on all categories of lands and all subjects of territorial intercourse; the industrial - that is made by ministries and committees and federal agencies based on the principle of the accountability of industries and organizations that are responsible for the giving of rights of land properties" $"$. The example of the general state regulation of territories is given in Chapter 2 of the Code of Belorussia Republic concerning the state regulation of the territorial business in Belorussia by "the President of Belorussia, the Cabinet of Ministers of Belorussia, the State Committee of the Land Property of Belorussia and other specially administrated republican agencies of the state intercourse, the regional, The Minsk urban, the urban (belonging to towns of the regional administration), regional, rural, rural and urban administrative committees according to their competences that are regulated by the Code and other Acts of Legislation"13.

Thus, the State Property Committee of Belorussia is active in the regulation of territorial intercourse on the basis of "the state regulation and the administration in the sphere of usage and protection of lands while the regulation of the order of the elimination and the giving of territorial areas, the transformation of land areas from one category to another" ${ }^{\prime \prime}$. The competence of the State Committee of Land Property in Belorussia in the sphere of usage and protection of lands leads the

10 Закон Республики Молдова "О нормативной цене и порядке купли-продажи земли" № 1308-XIII от 25.07.1997. URL: http://www.casa-ta.info/zakon/zakon4.php?lang=ru. (дата звернення 02.02.2020).

11 Земельний кодекс Республіки Казахстан від 20.06.2003 г. № 442-II. URL: http://online.zakon.kz/. (дата звернення 02.02.2020).

12 Дамдын О.С. Государственное регулирование земельных отношений / О.С. Дамдын // Молодой ученый. 2011., № 5., Т. 1. С. 176.

13 Кодекс республіки Білорусь про землю від 23.062008 г. № 425-3. URL: http://www.etalonline.by/?type=text\&regnum=Hk0800425\#load_text_none_1_6 (дата звернення $02.02 .20)$

${ }^{14}$ Официальный сайт Государственного комитета по имуществу Республики Беларусь. URL: http://www.gki.gov.by/ru/activity_branches-land/. (дата звернення 02.02.20). 
state policy, administrates the order as for the revival, the pointing out, the fixing of borders of land areas, provides the development of projects of regional systems of usage and protection of land resources, schemas of the land administration of the administrative and the territorial unities, points out the order of the leading of the land management, organizes it's leading and so on (Article 26. The Code of Belorussia about Lands) ${ }^{15}$.

In Ukraine the agencies of the local administration (regional, Kiev and Sevastopol municipal, regional, regional in towns, rural, rural and urban council) perform the administrative functions in the sphere of the territorial intercourse according to Articles 8-12 TC of Ukraine, Laws of Ukraine "The Urban Municipality in Ukraine" dated by the $21^{\text {st }}$ of May 1997 (with the corresponding changes), "The Capital of Ukraine - the Heroic Town Kiev" dated by $15^{\text {th }}$ of January 1999 . To their sphere of responsibility belong: the administration of lands of territorial municipalities; the creation of conclusions as for elimination (buying) and giving land areas from the state lands by means of agencies of the administrative power; the regulation and the change of borders of the corresponding administrative and territorial units; the organization of the land management; the provision of the realization of the state policy in the sphere of the usage and the protection of lands etc. The peculiarity of the state industrial regulation of lands is the inner-industrial administration of lands is made by industries and organizations that own lands. For example, agencies give normative acts in the sphere of the administration of lands that are obligatory for the realization in the sphere of the judicial person and are accompanied by actions of the disciplinary acts. The process of the legal regulation of the territorial intercourse is made on the basis of regulative and protective and warning norms.

The basis of the legal regulation of the territorial business is "the rational usage of territorial resources in CIS" that is guaranteed by different complexes of legal actions, such as:

1. The stimulation of the purposeful usage of territorial areas:

a) the charge of the land management (for example, "land areas that are the property are rated by the territorial tax according to the taxing laws of Kazakhstan Republic" - Article 9 of The Territorial Code of Kazakhstan Republic) ${ }^{16}$;

15 Кодекс республіки Білорусь Про землю від 23.062008 г. № 425-3. URL: http://www.etalonline.by/?type=text\&regnum=Hk0800425\#load_text_none_1_6 (дата звернення $02.02 .20)$

${ }^{16}$ Декларація про принципи міжнародного права, що стосуються дружніх відносин та співробітництва між державами відповідно до Статуту Організації Об'єднаних Націй від 24.10.1970. URL: http://zakon4.rada.gov.ua/laws/show/995_569/card2\#Card (дата звернення 02.02.20) 
b) the usage of benefits and advantages to owners and land managers (for example, "the provision of benefits of the land tax that are explored firstly and lands of irrigation that are in the process of the ameliorative improvement according to the legislative acts", - Article 83 of The Territorial Code of Uzbekistan Republic) ${ }^{17}$;

c) the usage of sanctions towards people who violate the process of the usage of lands (for example, "administrators, owners of land areas and land managers are responsible for the regulated by the law of Kirgizstan Republic social, administrative and criminal responsibility for the violation of the territorial laws" Article 120 of The Territorial Code of Kirgizstan Republic) ${ }^{18}$.

2. The ways of the elimination of reasons and conditions that cause the irrational usage of land areas:

a) the regulation of the state system of the giving and the elimination of lands (for example, "the right of the private property on territorial areas is withdrawn according to the court decision while the confiscation of the land area" - Article 80 of The Territorial Code of Belorussian Republic) ${ }^{19}$;

b) the regulation of the need to correspond the ownership of land areas with the proper state agencies (for example, "the giving of the judicial persons of Turkmenistan territorial areas for the development of the useful resources is made after the formation of the mountain management with the condition of the further remediation of the areas and according to the laws of Turkmenistan in the sphere of nature protection" Article 85 of The Territorial Code of Turkmenistan",20;

c) the creation of the scientifically proved calculations that illustrate the consequences of the usage of the given lands (for example, "the protection of lands is done with the help of the usage on practice scientifically proved norms of the land usage that reflect the optimal structure of the usage and the effective organization of the territory on the basis of the land management" Part 2, Article 34 of The Territorial Code of Azerbaijan ${ }^{21}$.

3. The way of the pointing out of the operative stopping of the national of the land areas (for example, "in cases when the agency has ordered to

17 Земельний кодекс Республіки Узбекистан від 30.04.1998 № 598-I. URL: http://www.lex.uz/pages/GetAct.aspx?lact_id=149947. (дата звернення 02.02.20).

18 Земельний кодекс Киргизької Республіки від 02.06.1999 № 46. URL: http://online.adviser.kg/Document/?doc_id=30241294. (дата звернення 02.02.20).

19 Кодекс республіки Білорусь про землю від 23.06 2008 г. № 425-3. URL: http://www.etalonline.by/?type=text\&regnum=Hk0800425\#load_text_none_1_6. (дата звернення 02.02.20).

20 Кодекс Туркменістану “Про землю”. URL: http://parahat.info/law/kodeksturkmenistana-o-zemle. (дата звернення 02.02.2020).

21 Земельний кодекс Азербайджанської Республіки від 16.07.1996 № 695-IQ. URL: http://eco.gov.az/az/435-azerbaycan-respublikasinin-torpaq-mecellesi. (дата звернення 02.02.20). 
withdraw reasons of the irrational usage and the protection of lands it has the right to make the checking of the mentioned actions in the regulated term" Article 85 of The Territorial Code of Uzbekistan) ${ }^{22}$.

4. The way of the regulation of the withdrawal of violations of the rational usage of lands (for example, "the protection of lands comprises from the system of legal, organizational, economic and other activities made with the purpose of their rational usage, protection and the unproved withdrawal of the more valuable lands from the circulation of the agriculture and the forest household, the protection from the harmful natural and anthropogenic actions and the revival and the increasing of the futility of lands and forests" - Part 1, Article 34 of The Territorial Code of Azerbaijan).

As a conclusion, the legal provision of the rational usage of lands as the basic way of the legal regulation of the territorial intercourse is the complex of legal actions the systematic usage of which lets to solve tasks of the land policy of the country of CIS. It should be mentioned that while the regulation of different ways of the territorial intercourse and on the basis of the subdivided legal regulation of the Territorial Code of CIS divide spheres of the activity of the land laws, laws about the protection of the environment and the rational usage of the natural resources, etc.

This principle lets optimally to regulate the territorial intercourse with the actualization of the peculiarities of the object of the business and their ecological relations with other natural objects.

Among the problems of the state regulation of the territorial business should be mentioned the following problems: the old territorial legislation in the sphere of the state regulation of the territorial intercourse that doesn't correspond to the modern development of the social and the economic intercourses in the state; "the ramified" system of the state agencies in the sphere of the state regulation of the territorial intercourse; the problem of the correlation between state agencies of different levels and spheres of the influence on the territorial business (for example, the interrelation between agencies that control the information about territorial areas and agencies that form rights on them ${ }^{23}$; the dubbing of functions of state agencies (for example, the repetition of identical items of the inventory accounting); the absence of the united system of the accounting, the safe and the usage of the informational resources as for the land areas; the concentration of the great variety of land areas in some great structures (latifundists); the great level of

22 Земельний кодекс Республіки Узбекистан від 30.04.1998 № 598-I. URL: http://www.lex.uz/pages/GetAct.aspx?lact_id=149947. (дата звернення 02.02.20).

23 Жуков М.А. Актуальные проблемы регулирования земельных отношений / М.А. Жуков // Весник ОГУ. 2003., № 3. С. 115. 
the corruption in the sphere of the state regulation of land business; the stopping of the activity of the majority of subjects of property in the sphere of the usage of different categories of lands; the elimination of lands of the agricultural sphere and inputting them into the fund of the subdivision; the change of approved usage of lands; the difficulties of the transference from the system of the state regulation of the territorial intercourse when the one owner of the land is the state and the system of the state administration of territorial business while the pluralism of owners of the land; the irrational usage of lands that leads to the degradation of lands; the non-effective realization of laws in the sphere of the privatization of the agricultural lands; the absence of the effective system of activities as for the reflection of the negative activity of water and wind erosion of lands; the negative results of the land reform (the fall of the agricultural industry, the urbanization of the society, the intension of the inhabitants of the agricultural regions, the dependence from countries-exporters, etc.); the small percentage of the documental formation of the right of the usage of lands; the bureaucracy in the sphere of the formation of the right on the usage of lands for the leading of the farming industry; the spread orientation of the state administration of the territorial business etc.

We consider, that the priority level of the improvement of the state regulation of the territorial intercourse is the following: the creation of the one informational space for the accounting of lands on the state and the regional levels (for example, the one bank of resources about the territorial areas with the unified form of the information for all state agencies in the sphere of the regulation of territorial business and the ability of the available information in the real time); the improvement of the organizational structure of the interrelation between subjects of the state administration of land business; the improvement of the system of the division of land areas by means of the auction, free and beneficial subdivision of lands that are needed for the development of the social sphere of the state and the territorial authorities; the formation of the one viewpoint on the organization of the state administration of the territorial business and the usage of the land; the creation of the one for Ukraine scheme of the land management on the territory of the state.

\section{The Mechanism of the Legal Regulation of the Right of the Private Property on the Land in CIS}

The actuality of the investigation of the problem of the private property on lands in CIS is determined by the fact that in the USSR the private property on the land didn't exist and, accordingly, didn't exist the normative, the legal and the theoretical reasoning and the development. It should be mentioned that such a state of affairs in the legal regulation of the territorial intercourse at the 
soviet times till the present times has the negative influence on the development of the territorial legislation in CIS in this point.

While the land reform in some countries of CIS was withdrawn the monopoly of the state property of lands and were introduced different forms of the land property. The legislation of CIS states and identifies the variety of forms of the land property. It's influence and the systematization of forms lets to make the following conclusions: 1) the right of the private property of people on land areas is legally stated in 10 countries of CIS; 2) the right of the private property on lands of juridical persons is regulated legally in 8 countries of CIS; 3 ) the right of the common property on the land area is legally stated in 5 countries of CIS; 4) the right of the state property on lands is legally stated in all the countries of CIS; 5) the right of the municipal property on lands is legally stated in 6 countries of CIS; 6) the right of the property of foreigners and people without citizenship is legally stated in 6 countries of CIS; 7) the right of the property of the foreign countries on lands is stated legally in 4 countries of CIS.

There are forms of the property on lands in the legislation of CIS that is unique (the one) and is stated in the Territorial Code. For example, only in the Territorial Code of Russian Federation is pointed out the social property of the spouse on the land area, the common property of the farming industry on the land area and the property of the condominium. The right of the property of the international organizations on lands is determined in the territorial codex of Tajikistan Republic and according to which the one form of the property on the land is the property of the state on the land.

The conclusion: all forms of property on the land in CIS may be subdivided on two big groups: the private and the public property on the land. Different forms of the property influence on the territorial intercourse in the country.

In the modern theory of the territorial law the majority of scientists are against the existence of the private property on the land. For example, M.H. Vahaev proves the statement about "the private property on the land is considered to be the great freedom of the circulation of the land that is the great danger of the domination of the material values and interests while the usage of the land protection and safe of the cultural inheritance" ${ }^{24}$. The general position of the opponents of the private property on the territory is based on the following factors: the understanding of the right of the private property existing from the USSR; the irrational usage of the land by private juridical and physical personalities; the danger of the ecological safety;

${ }^{24}$ Вахаев М.Х. Дискуссионные вопросы частной собственности на землю в России / М.Х. Вахаев // Журнал российское право. 2006. № 5. С. 79-86. 
"the encroachment" on the state unity. Arguing with the position of these authors as for "the inadmissibility of the right on the private property", we consider that the right of the private property on the land is one of the main right in every democratic country. Thus, T.E. Chernavina states that for the outlining of the specification of the right of the private property on the land should be pointed out: the subject of the right of the property; the object of the right of the property; the contents of the right of the property; the measure of the eligible right of the property; guarantees of the right of the property ${ }^{25}$.

Summarizing approaches for the understanding of the right of the private property on the land we may state that the right of the private property on the territory is the form of the right of the property that presupposes the right of the usage, the owning, the administration of the territorial area or it's parts by private juridical and physical persons. The right of the private property on the land of citizens and juridical persons emerges while the privatization of the state and the municipal lands as a result of the inheritance, the giving, the buying-selling, the exchange or other agreements concerning lands as a result of the pointing out of the land area as an input to the statutory (share) capital of the juridical person ${ }^{26}$.

The criteria for the subdivision of forms of the private property is the subject of the right of the private property. According to this criterion is pointed out the right of the private property of physical persons and the right of the private property of juridical persons. It should me mentioned that in the Ukrainian territorial code the legislator spreads maximally the list of physical and juridical persons who can be subjects of the right of the private property. This tendency is observed in laws of other countries of CIS. That's why, the subjects of the right of the private property are: citizens of the country, foreigners, people without citizenship (according to the law); juridical persons, residents of the country (industries, cooperatives, social and religious organizations (unities), associations, unities), foreign and international organizations, united industries, social organizations, etc.

Investigating in details the subject structure of the right of the property on the land in Ukraine, should be mentioned the following: the subjects of property on the land of the industrial sphere are: the citizens of Ukraine; juridical persons and the created unities of citizens of Ukraine; the state agencies of the state power; the territorial unities of villages, towns and regions as agencies of the local administration. The subjects of the

25 Титова Н.Г. Рынок земли и его роль в повышении конкурентоспособности экономики / Н.Г. Титова // Экономические науки Вестник Нижегородского университета им. Н.И. Лобачевского, 2010. № 3 (2). С. 612-615.

26 Япаров Г.Х. Эффективное управление земельными ресурсами / Г.Х. Япаров // Ватандаш, 2015. № 7. С. 11-24. 
administration of lands belonging to the common property of territorial unities of a city are regional councils.

It should be mentioned that all forms of the property in CIS have the equal value and for foreigners or people without the citizenship is regulated "the national regime" (according to rights and duties the legislator equals them the citizens of the country ${ }^{27}$. In spite of "the national regime" for foreign physical and juridical persons the right of property on the land is strictly measured. For example, according to the Law of Ukraine foreigners can't be owners of lands of the agricultural sphere and can't be owners of parts of this category of lands.

In some countries of CIS is regulated that foreigners, juridical persons and people without citizenship can't own in private sphere land areas on the borders of the country (Ukraine, Kazakhstan Republic, Kirgizstan Republic, etc.)

The important fact in the investigation of the right of the private property on lands is the outlining of the object of the property. The objects of the property are individually measured land areas that as for the law have transferred to the subject and are in their property, usage and regulation.

According to Article 373 of the Civil Code of Ukraine the right of the private property on the land area is spread on the high (the soil) level in measures of this area, on water objects, forests, perennial planting, on superficial space, the high and the deep of which are necessary for the building of living, industrial and other buildings ${ }^{28}$. Accordingly, the owner of the land area has the right to use all that is on superficial space over the land area if the other point is not regulated in the law as for soils, the usage of the air space, and as for law rights of other persons. This point is investigated in details in the Territorial Code of Ukraine "the right of property on the land area is spread on space that is on and under the level of the land area in high and deep necessary for the building of houses, industrial buildings and other buildings" (Part 3, Article 79) ${ }^{29}$.

It should be mentioned that the territorial law in the majority of countries of CIS (Ukraine, Belorussia, Moldova and others) presupposes the ownership of any land areas in exclusion of some types of land areas that can't be the ownership of citizens or judicial persons (land areas eliminated from the circulation of land areas, restricted in the circulation). The amount and the variety of land areas that are in the private property is not restricted in exclusion of the regulated restrictions by the law. For example, according to the point of the Territorial Code of Kazakhstan Republic in the private

27 Фучко А. С. Конституционные основы права частной собственности на землю / А. С. Фучко // Вестник НГУ. Серия право, 2012. Т. 8. Вып. 2. С. 79-80.

${ }^{28}$ Цивільний кодекс України від 16.01.2003 № 435-IV URL: http://zakon3.rada.gov.ua/ laws/show/435-15/paran155\#n155 (дата звернення 02.02.20)

29 Земельний кодекс України від 25.10.2001 № 2768-III. URL: http://zakon3.rada.gov.ua/ 
property may be land areas for the agricultural or the farming activity, the private farming industry, the forestation, the planting, the individual household, and the given land areas for the building or land areas built by the industrial and non-industrial, housing, buildings (homes, houses) and the building complexes, including lands devoted to the service of buildings (homes, houses) according to their dedication. The right of the private property on the land has the absolute power of the owner that is contradictive to the passive duty of the non-regulated circle of persons who are abstained from the violation of such a right.

There are different ways to protect the right of property of the land: 1) ways to protect the right of property leaded on the protection of the violated right (vindication and negative claims); 2) ways to protect the right of property on the land leaded on the prevention of the violation of the right of property.

The peculiar place among ways to protect the right of property on the land is occupied by guarantees of the right of the private property on the land.

The analysis of laws in CIS lets conclude that the guarantees of the right of the private property may be of three kinds: On the international level. The main international normative and law act, that includes norms of the guarantee of the form of property, is the European Convention about the protection of humans' rights and main freedoms dated by 1950 (further in the Article - the Convention). In the Article 1 of the Convention is proved that "every physical and juridical person has the right on the respect of property. Anybody can't be refused from the property in spite of the interests of the society and on conditions according to the law and general principles of the international law"30. The Convention was ratified in such countries of CIS: Armenia, Azerbaijan, Moldova, Ukraine.

The conclusion: the ratification of the Convention by several countries of CIS gives the possibility of citizens of these countries to appeal to the European Union on Human Rights in Strasburg in case their right of the private property has not been defeated by the judicial system of the country of their citizenship.

On the constitutional level (for example, in the Point 1, the Article 13, of the Constitution of Ukraine is written "the land, it's subsoil, atmospheric air, water and other natural resources in the borders of Ukraine, natural resources of the continental borders, excluding the (sea) economic zone are the objects of the property of Ukrainian people. The power of land management is created by agencies of the state power and agencies of the local management

30 Протокол до Конвенції про захист прав людини і основоположних свобод від 20.03.1952. URL: http://zakon5.rada.gov.ua/laws/show/994_535 (дата звернення 03.02.20) 
according to the Constitution". In the Article 14 is stated the right of citizens and the unities to have the power to own lands "The right of property on the land is guaranteed. This right is given and realized by citizens, judicial persons and the state according to the law"31. The Constitution of Ukraine includes the strict constitutional guarantees of the right of the private property on the land, approves the general guarantees of the protection of rights and freedoms of a human and a citizen. Constitutional articles proclaim the right of citizens to own in the private property the land, are the legal constructions on the basis of which are created and realized norms and institutions of the territorial law $^{32}$. In this case the actual is the opposition by V.D. Zorkin about the role of the Constitutional Court of Ukraine. The scientist points out that "in the decisions the Constitutional Court has formed legal positions that reveal the constitutional sense of the right of property, the contents of the given right, borders of the realization, approved restrictions and guarantees of the judicial protection. This decision is of the precedent nature and is obligatory for all agencies, especially for the legislators and judges".

The conclusion: the guarantee of the right of property on the land is given to every legal owner of the land; the protection of the right of property while the direct and the indirect violation; the Constitution of Ukraine guarantees the protection of the right of property in spite of the form of property. The disadvantage of the constitutional regulation of the right of property is that in the constitutional norms is not included the direct instructions concerning the obligatory rational and effective usage of lands that are in the private property of physical and private judicial persons.

3. On the level of the territorial coded law and the industrial legislation (for example, in the Article 3 of the Territorial Code of Moldova is pointed out the statement that "lands of Moldova may be in the public and the private property",33).

In territorial coded law of the majority of countries of CIS the question of the private property is identified in separate chapters with the detailed explanation of categories of lands that could be objects of the private property according to the aim of their usage, the order of the buying and elimination etc.

Except the mentioned types of guarantees of the private property on the land D.A. Olnev divides guarantees of the private land property according to the mechanism of the protection on the following types: the judicial

31 Конституція України від 28.06.1996 № 254к/96-BP. URL: http://zakon2.rada.gov.ua/ (дата доступу 02.02.20)

${ }^{32}$ Харитонов Є.О. Цивільне право України : підручник / Харитонов Є.О., Старцев О.В. Вид. 2, перероб. і доп. К.: Істина, 2007. 816 с.

Земельний кодекс Республіки Молдова від 25.12.91 № 828-XII. URL: http://www.law-moldova.com/laws/. (дата доступу 02.02.20) 
guarantees of the right of the private property on the land (the right to appeal to a court on the protection of the right of the private property on the land); the administrative guarantee of the right of the private property on the land (the right on the individual or collective appeal to the state agencies and the local land managements with the protection of the right of the private property on the land); the guarantee of the self-protection of the right of the private property on the land (for example, according to the points of the Constitution of Ukraine "the state guarantees the protection of all rights of subjects of property and management, of the social leading of the economics. All subjects of the right of property are equal at the law").

The conclusion: the mentioned guarantees of the right of the private property on the land are marked by certain difficulties of the realization. It is pointed out the low level of the realization of judicial guarantees of the right of the private property on the land (for example, Ukraine occupies the leading place on the amount of contradicted appeals and on the amount of the final decisions concerning the violation of humans' rights).

Administrative guarantees of the right of the private property on the land is restricted by the giving to the state agencies and the local managing agencies different documents concerning the violation of humans' rights, the pre-trial solvation of the argument and the stopping of the criminal actions of the third persons. The self-protection of the private property on the land should correspond to such demands: to correspond to the way and the nature of the violation and may be used in case if the done (possible) violation is serious then refused.

The regulation of the intercourse of the private property on the land in CIS is based on the balance of interests of the private owner and the whole society. For example, in the Constitution of Ukraine is supported the need to regulate the restrictions, stating in the Article 41 the following statement about "the usage of property can't harm rights, freedoms and dignity of citizens, of the society, make harm to the ecological situation and natural quality of the land"34.

In the solvation of the question about the property on the land should be considered the national interests of the territorial unity and the state protection.

The conclusion: there aren't "the unrestricted" land managers in CIS, the right of property is restricted in the interests of the state and the society.

Including the above mentioned information and summarizing the statements of the territorial laws in CIS, we may outline the following peculiarities of the right of the private property on the land: 1) while the

34 Конституція України від 28.06.1996 № 254к/96-BP. URL: http://zakon2.rada.gov.ua/ (дата доступу 02.02.20) 
realization of the right of the private property on the land exists the need to carry ecological demands of the usage of lands, the need to protect rights and legal interests of other participants of the legal business; 2) the right of property on the land is restricted in socials aims because the land and other natural resources are the basis of life and activity of people living on the corresponding territory; 3 ) "the triad" of rights the owner of the land area carries in the measure of the existing law; 4) the land laws of CIS comprises the main list of ways of the protection of rights of land owners. The important point while the appeal to the court protection of the private property on the land is the right choice of the way of the protection of the violation of the right that corresponds to the level of the violation; 5) the owner has the right to alienate the land area to the property of other people, to give them the right of the property, the usage, the administration of the land area, give it to the mortgage, etc.; 6) the owning of the land is carried by the way of the stating the borders of the land area on the location; 7) the right of property on the land is regulated by the civil, the territorial, the administrative, the labor, the criminal, the taxing and the budget laws.

In spite of positive results of the territorial reforms in CIS may be outlined the following problems in the sphere of finance and development of the private property on the land: state agencies have approved the controversial legislative acts in this sphere; in all countries of CIS is pointed out the violation of rights of humans and the citizen on the natural resources; the high level of the corruption in the sphere of territorial intercourse; the low level of the inputs into the intercourse with the participation of private owners, etc.

We consider that problems in the sphere of the formation and the development of the private property on the land influence negatively on the destiny of the private property on the land in Ukraine and the effectiveness of the realization.

\section{The Market of Lands in CIS}

The becoming of the right of the private property on the land, the change of the administrative and the command regulation of territorial intercourse on the market regulation determine the formation and the development of the market of lands in CIS. The market of the land is the unseparated part of the economics of any developed country. The question of the legal regulation of the market of the land is actual for the majority of scientists who investigate it in the scientific researches. The land market is the part of the system of the territorial intercourse the regulators of which are the right of property (the owning, the usage, the administration), the possibility to transfer this right (the rent, the selling, the guarantee, etc.), the competitiveness (the free choice of a participator), the charged evaluation of the price free monitored on the land. 
The meaning of the land market in CIS is determined by the following factors: 1) the land market is the segment of the market economics that provides the increasing of the level of the competitiveness; 2) the land market is the way to realize business between subjects of the intercourse; 3) after the realization of territorial reforms in CIS emerged the majority of owners who don't have the relation to the agricultural sphere; 4) any land area may belong to any new owner and any land area has the fixed price.

The peculiarities of the land market: 1) the demand and the proposition on the land market is identified by the political system of the society, the geographical and the historical ways of the development of the country, the state of the infrastructure of the region and the level of the development; 2) the irrational price of the land as the object of nature the free natural gift; 3 ) the differentiation of land areas as for the category, the place of the location, the qualitative peculiarities and inputs into the increasing of the futility; 4) the restriction of the proposition of land resources according to the increase of the amount of private owners of land areas who consider not to sell their areas but to give them on rent for the input; 5) the formation of agreements on the land market demands the obligatory state registration and the complex, the charged juridical support; 6) the active activity of professional agents while the agreement on the land market; 7) the lack of land areas in towns; 8) the majority of land areas rarely change the owner; 9) the land market creates and supports the business of lands as the values, presupposes the maximal productive usage, creates mechanisms of the transference of the land to owners who can manage lands effectively.

Structurally, the land market in CIS is the subject of the market that comprises: buyers and sellers; renters and landlords; professional agents (agencies on operations with real estate, evaluators, notaries).

As for the formal criteria the land market in CIS is that is realized. The problems of the land market in CIS are the following:

1. The imperfection of the inventory evaluation and the accounting of lands: a) the choice transfer in the inventory evaluation of lands (for example, the inventory system of the separate countries of CIS was planned in the direction of the evaluation of the most perspective rating lands but not in the direction of the creation of the inventory plans; b) at the present moment agricultural land areas that are separated physically are not identified on the location and can't be objects of the inventory accounting and the registration; c) the inventory value of objects economically is not proved because the accounting is oriented on the technical and the juridical peculiarities of lands; d) the part of these lands can't be objects of the inventory accounting because these areas are not separated on levels of property and are the property of the state. 
2. The free land invasion.

3. The absence of the effective organizational and economical mechanism of the land management.

4. The decrease of the futility and the financing results of the activity of the agricultural industries, "the neglect" of the great areas of lands of the agricultural sphere.

5. The existence of the system of the legislative and the practical restrictions on the land market.

6. The general percentage of lands in the circulation from the general land fund in CIS is minimal.

7. The domination of business of land renting over the selling.

8. The formation of local (regional) markets of lands with the specific policy of prices and "the scattering" of prices around subjects of the market.

9. The land market proves the protection from the uncontrolled attitude to lands.

10. The price of the land area on the land market is formed without the connection to the usefulness.

The attention on the land market is given to the danger of the criminal offences in the sphere of the land circulation. To such a group belong the following crimes: the making the non-legal agreements as for lands by means of the falsification of documents that state the right of property on the land; the bribe of authorities with the aim of the non-legal owning of the land area; the violation to the agreement with the land area or the refuse of the realization; the violation to the elimination of the right of property on lands areas; the demand of a bribe for the owning of the land area; the registration of the non-legal lands agreements; the actions leaded on the bankrupting illegal to the buyers of industries with the aim to own the real estate (land areas), etc ${ }^{35}$.

The increasing of the open economics in CIS, the need to increase the competitiveness of subjects of the agricultural sphere demand nowadays the improvement of the land market on the basis of the further regulation of the business of the land management.

To our mind, ways to improve the land market in CIS and in Ukraine are: the need of the complex solvation of the question about the formation of the state land policy and the formation of the corresponding agency of the administration of the land policy; the formation of the legal basis of the parallel development of the land market in some countries of CIS, the

35 Москалькова Т.Н. Рынок земли и преступления в сфере земельного оборота/ Т.Н. Москалькова // Национальные интересы: приоритеты и безопасность. М.: ООО “Издательский дом ФИНАНСЫ и КРЕДИТ”, 2008. № 1 (22). С. 24-26. 
infrastructure of the land market of the agricultural sphere as a result of the transformation of the land to those who can use lands effectively and pay the high rent; the effective ways to oppose to the land "raiding" on the land market; the improvement of the criminal and the legal regulation of the protection of lands; the increasing of the legal protective practice in judicial and police agencies in such a sphere; the inventory accounting and the monitor of lands; the protection from the unproved transference of lands of the agricultural sphere to the category of less effective forms of usage; the optimization of taxes of the agricultural lands; the leading of the systematical and the institutional changes of the land market (the effective infrastructure of the land market is the unity of systems, services, industries and organizations that serve the market and provide the normal regime of the functioning; the complex of ways to the economical circulation and the effective administration of the land area as the economic object (the basic functions are: the choice of the best variant of the development of the object, the provision of the optimal scheme of the financing of the project, the retranslation of the international experience of the innovative technologies, the formation of the modern informational sphere; the creation of the territorial banks and exchange, etc.

We conclude that the state regulation of the territorial intercourse is the aimed activity of state agencies of the legal, the economical and the organizational nature that is leaded on the regulation of the business in the sphere of the rational usage of lands, their protection, the protection of owners.

The basic problems of the state regulation of the territorial business are the old land laws in the sphere of the state regulation of the land business; "the spread" system of the system of the state regulation in the sphere of land intercourse; the problem of the interrelation between state agencies of different levels and spheres of the influence on the land business; the dubbing of functions of state agencies; the absence of the united system of the accounting, the safe and the usage on the informational resources the information about land areas; the concentration of the great variety of land areas in separate great structures, etc.

The priority way to improve the stat regulation of the land intercourse is: the creation of the one informational space for the land accounting on the state and regional levels; the improvement of the organizational structure of the business between subjects of the state administration of the land business; the improvement of the system of the division of land areas; the formation of the one point on the organization of the state administration of land intercourse and the usage of lands; the creation of the one schema of the land management in the territory of the country. 


\section{CONCLUSIONS}

The territorial laws of the majority of countries in CIS (Ukraine, Belorussia, Moldova and others) presupposes the private property of land areas in exclusion of some land areas that can't be properties of citizens and the judicial persons (land areas, excluded from the circulation of land areas, restricted in the circulation). The amount and the price of land areas that are private properties are not restricted in the exclusion of cases when these restrictions are regulated by the law. The right of the private property on the land is of absolute nature, the right of the owner is opposed to the passive duty of the unregulated circle of persons to withdraw the violation of this law. Guarantees of the right of the private property are of three kinds: on the international level; on the constitutional level; on the level of the coded land law and the industrial law.

\section{SUMMARY}

Problems of the land market in CIS: the imperfection of the inventory evaluation and the accounting of lands; the violation invention of lands; the decreasing of the level of the futility; the damage of the financing of the agricultural industries; "the decreasing" of the great areas of the agricultural sphere; the existence of the system of the legal and the practical restrictions on the land market, etc.

Ways to improve the land market: the need of the complex solvation of the question as for the formation of the state policy and the formation of the corresponding agency; the formation of the legal basis of the parallel development of the land market of the infrastructure of the land market of the agricultural sphere as a result the agricultural land will be transmitted to those who can use it effectively and pay higher taxes; the effective ways to oppose land "raiders" on the land market, etc.

\section{REFERENCES}

1. The Constitution of Ukraine on June 28, 1996 No. 254k/96-VR. URL: http://zakon2.rada.gov.ua/

2. Constitution of the Kyrgyz Republic on 05/05/1993. URL: http://www.gov.kg/?page_id=263\&lang=en

3. Declaration on the principle of international law, that friendly friends and nations must agree on the status of the Organization before the Statute of the Organization of the National Assembly on 10.24.1970. URL: http://zakon4.rada.gov.ua/laws/show/995_569/card2\#Card

4. The Civil Code of Ukraine dated 16.01.2003 No. 435-IV. URL: http://zakon3.rada.gov.ua/laws/show/435-15/paran155\#n155

5. The Water Code of Ukraine dated 06.06.1995 No. 213/95-BP. URL: http://zakon3.rada.gov.ua/laws/show/213/95-\%D0\%B2\%D1\%80

6. The Code of Turkmenistan "On Land". URL: http://parahat.info/ law/kodeks-turkmenistana-o-zemle. 
7. The Land Code of the Republic of Moldova dated 25.12.91 No. 828-XII. URL: http://www.law-moldova.com/laws/.

8. The Land Code of the Republic of Azerbaijan on July 16, 1996 No. 695-IQ. URL: http://eco.gov.az/az/435-azerbaycan-respublikasinintorpaq-mecellesi.

9. The Land Code of the Republic of Uzbekistan dated 30.04.1998 No. 598-I. URL: http://www.lex.uz/pages/GetAct.aspx?lact_id=149947.

10. The Land Code of the Kyrgyz Republic on June 2, 1999, No. 46. URL: http://online.adviser.kg/Document/?doc_id=30241294.

11. The Land Code of the Republic of Virmeniya від 02.05.2001. No. 3P-185. URL: www.parliament.am/legislation.

12. The Land Code of Ukraine vid 25.10.2001 No. 2768-III. URL: http://zakon3.rada.gov.ua/.

13. The Land Code of the Republic of Kazakhstan dated June 20, 2003. No. 442-II. URL: http://online.zakon.kz/.

14. The Code of the Republic of Belarus on the land of June 23, 2008. No. 425-3 URL: http://www.etalonline.by/?type=text\&regnum=Hk0800425\# load_text_none

15. The Land Code of the Republic of Tajikistan dated 13.12.1996. URL: http://tabiat.narod.ru/LAWDB/1_10.html.

16. The Land Code of the Republic of Uzbekistan dated 30.04.1998 No. 598-I. URL: http://www.lex.uz/pages/GetAct.aspx?lact_id=149947.

17. The Law of Ukraine "On the State Land Cadastre" dated 07.07.2011 No. 3613-VI. URL: http://zakon5.rada.gov.ua/laws/show/3613-17

18. The Law of the Republic of Moldova "On the Normative Price and Procedure for the Sale of Land" No. 1308-XIII of 07.25.1997. URL: http://www.casa-ta.info/zakon/zakon4.php?lang=en.

19. Decree of the President of Ukraine "On the Strategy for Steel Development" Ukraine-2020 "dated 12.01.2015 No. 5/2015. URL: http://zakon2.rada.gov.ua/laws/show/5/2015

20. The Supreme Court of Ukraine resolves "On the practice of suing courts of land legislation in the process of reviewing civil law", dated April 16, 2004 No. 7 URL: http://zakon5.rada.gov.ua/laws/show/va007700-04

21. Borisov A.B. Big economic dictionary / A.B. Borisov. M.: Book world, 2003. $895 \mathrm{p}$.

22. Borodin S.S. Land law. General part: Lecture course / S.S. Borodin. $\mathrm{SPb}:$ SPbGUAP., $2000.215 \mathrm{~s}$.

23. Vakhaev M.Kh. Discussion questions of private ownership of land in Russia / M.Kh. Vakhaev // Journal of Russian Law. 2006. No. 5. P. 79-86.

24. Damdyn O. S. Land law: concept, subject and method of legal regulation / O. S. Damdyn // Young scientist. 2014. No 1. S. 211-213.

25. Damdyn O. S. State regulation of land relations / OS Damdyn // Young scientist. 2011. No 5. T. 1. S. 175-177. 
26.Zhukov M.A. Actual problems of regulation of land relations / M.A. Zhukov // Vesnik of OSU. 2003. No3. S. 112-116.

27. Zaitsev O.L. The right to inherit land in Ukraine: Abstract. dis. ... cand. legal Sciences: 12.00.03 / O.L. Zaitsev. National University of Internal Affairs - Kharkov, 2000. P. 9.

28. Kalinin N.I. Legal regulation of land relations in Russia / N.I. Kalinin - M.: Cooperation project "German-Russian Agrarian and Political Dialogue", 2011. 6 p.

29. Kolesnichenko VV. Principles of law of the European Union: the most theoretical understanding: abstract. dis. Cand. legal Sciences: 12.00.01 / Kolesnichenko Vadim Vasilovich; Odeska is a national legal academy. Odessa, $2010.22 \mathrm{p}$.

30. Lunyachenko A. V. The legal regime of agricultural land belonging to citizens by right of ownership: Dis. ... cand. legal Sciences: 12.00.06 / Lunyachenko Anatoly Vasilevich; Odessa National Law Academy. - O., 2002. $170 \mathrm{~s}$.

31. Makhortova O.A. The formation of the land market in the Russian Federation. Access Mode: http://www.rae.ru/forum2012/pdf/3113.pdf

32. Medentsov A.S. Cheat sheet on land law. Access mode: http://www.razlib.ru/shpargalki/shpargalka_po_zemelnomu_pravu/index.php.

33. Moldovan VV Jurisprudence: the first-hand post. 2nd view. / V.V. Moldovan, L.I. Chulinda. - K : Center for Educational Literature, $2010.184 \mathrm{~s}$.

34. Moskalkova T.N. Land market and crimes in the field of land turnover / T.N. Moskalkova // National interests: priorities and security. - M.: LLC "Publishing House FINANCE and CREDIT", 2008. - No. 1 (22). S. 24-26.

35. Muntyan V.L. Legal protection of soils of the Ukrainian RSR / V.L. Muntean. - K : Scientific Thought, 1965. S. 29-33.

36. ECHR report for 2016, including previous years - Official website of the European Court of Human Rights. Access Mode: https://roseurosud.org/ espch/statistika-espch-1959-2016.

37. Official website of the State Property Committee of the Republic of Belarus URL: http://www.gki.gov.by/ru/activity_branches-land/.

38. The official website of the Federal Service for State Registration, Cadastre and Cartography. URL: https://rosreestr.ru/.

39. Polyakov II Theory of understanding the essence of the object of legal relations / II. Polyakov // Teaching notes of the Taurida National University named after V.I. Vernadsky: Series "Legal Sciences". - Tom. 19 (58), No. 2. - 2006. S. 113-117.

40. Protsenko E.V. The essence and legal content of the right of private ownership of land / E.V. Protsenko // Legal Thought. 2011. No 2 (64). S. 101-107. 
41. Direct and indirect state regulation of the economy. Access regime: http://econtool.com/gosudarstvennoe-regulirovanie-ekonomiki.html.

42. Stechenko D.M. State regulation of the economy: Nav. pos_b. 3-th view., Vypr. K., 2006.262 s.

43. Titova N.G. Land market and its role in improving the competitiveness of the economy / N.G. Titova // Economic sciences Bulletin of the Nizhny Novgorod University. N.I. Lobachevsky, 2010- No. 3 (2). S. 612-615.

44. Fuchko A.S. The constitutional basis of the right of private ownership of land / A.S. Fuchko // Bulletin of NSU. Series law, 2012. V. 8. Vol. 2. P. 76-82.

45. Kharitonov E.O. Civil law of Ukraine: fiduciary / Kharitonov E.O., Startsev O.B. - View. 2, reoff. i additional K : Istina, $2007.816 \mathrm{s.}$

46. Shvaika L.A. State regulation of the economy: Textbook / L.A. Shayka. K : Knowledge, 2006.435 s.

47. Yaparov G.Kh. Effective land management / G.Kh. Yaparov // Vatandash, 2015., No. 7. s.

Information about the authors: Stratonov V. M.,

Doctor of Science (Law), Professor, Professor at the Department of the Industrial Law, Kherson State University 27, Universitetska str., Kherson, 73000, Ukraine

ORCID: 0000-0002-7548-0630

Gavlovskaya A. O., $\mathrm{PhD}$ (Law), Professor, Assistant Professor at the Department of the Industrial Law, Kherson State University 27, Universitetska str., Kherson, 73000, Ukraine ORCID: 0000-0002-7973-7560

Pavlish P. V., $\mathrm{PhD}$ (Law), Deputy of the Verkhovna Rada of Ukraine 5, Hrushevskoho str., Kyiv, 01008, Ukraine ORCID: 0000-0001-5206-9307 